Volume 8, Issue 1, 361 - 375.

ISSN: $2165-8714$

http://www.eu-jer.com/

\title{
The Inclusion of Social Issues in the Curricula Adopted at the Elementary Education Level in Turkey
}

\author{
Fatmanur Ozen * \\ Giresun Universitesi, TURKEY
}

\author{
Temel Topal \\ Giresun Universitesi, TURKEY
}

Received: December 26, 2018 - Revised: January 8, 2019 - Accepted: January 14, 2019

\begin{abstract}
In Turkey, as in all countries of the world, education is regarded as the sole means of modernization, progress, civilization, productivity, and sustainability of all these things. The aim of the Turkish education system is to raise students with the national, moral and cultural values of the Turkish nation, to educate them as citizens of a social law state, and solve the existing or potential problems that may arise in the future. The most important document that shows how this aim will be achieved in the country is the curriculum. The purpose of this study is to reveal the frequency of the social issues included in the current curriculum at the elementary education level. Within the scope of the study, social issues presented by sociologists were established through e-Delphi panels, coded under seven titles by researchers, those who were thought to bring solutions to these problems were counted by descriptive analysis method in the specific aims, themes and achievements of the curriculum used at elementary level. Results show that curriculum adopted at the elementary education level include mostly issues related to individual life and individualization, socialization, democratic life and democratization while economic issues, and issues related to family, environment and urbanization are emphasized less. These findings are discussed with other research results.
\end{abstract}

Keywords: Social issues, education, curriculum, elementary curricula.

To cite this article: Ozen, F., \& Topal, T. (2019). The Inclusion of social issues in the curricula adopted at the elementary education level in Turkey. European Journal of Educational Research, 8(1), 361-375. doi: 10.12973/eu-jer.8.1.361

\section{Introduction}

Education and schools are "national icons" that people and governments established to provide their citizens with "national identity, information and science" (Hidmi, 2018). Education plays a significant role in "developing and shaping the manpower" that constitutes societies (Sanal, 2016, p. 118). As Varis (1998) puts it education: "equips the individual with the skills, tendencies and other forms of behavior that have practical value in the society they live in"; in this respect schools offer "a distinguished and controlled environment" to "improve individuals social skills and personal development" (p. 17). Akyuz (2012) evaluates the effect of education in general and that of school in particular, on the individual within the context of teacher's effect on the students via school, and classifies these effects under four headings: "socialization, causing behavioral change, training qualified manpower and personnel for various occupations, and creating leaders and intellectuals" (pp. 5-9). Then, the aim of the education system is to equip individuals with behaviors deemed necessary for collective living, provide them with professions and jobs in line with the areas of employment, and raise them as leaders that will rule the country one day.

We expect from public education, the main determinant of the human profile to be cultivated by countries: To teach the individuals their cultural tradition and enable them to improve that tradition to solve constantly changing life problems; to enable them to interact and establish meaningful relationships with the other individuals in the society; to enhance their creative ability necessary in every aspect of their life; to provide important values, like productivity culture, for good citizenship (Orogue, 1998). Then, from the teachers who rise the people of today, from the schools where the teachers provide teaching services, in short from the national education system which is one of the biggest instruments of national ideology, in the context of the products (students) they produce, to raise individuals (students) who solve constantly changing life problems.

In Turkish education system, the highest level advisory board of the Ministry of National Education (MoNE) is the Board of Education (BoE). BoE directs the education system by taking into consideration "the general purposes and basic principles of national education and universal values and standards, strives to improve the educational system based on national and social values together with the principles of quality, equality and efficiency". On its official

\footnotetext{
* Corresponding author:

Fatmanur Ozen, Giresun University, Special Education Department, Giresun, Turkey.

$\bowtie$ fatma.nur.ozen@giresun.edu.tr
} 
website BoE defines education as "a process involving the acquisition of knowledge, skills, attitudes, aesthetic sensitivity and positive behaviors and especially the cultural values in which the individual is born.". The presidency stresses that education should contribute to the "individual's quality of life" beside contribute to "the welfare, social and democratic development of the country" (MoNE BoE, Curriculum Monitoring and Evaluation System). Therefore, public education should solve both individual and social issues or to raise citizens who can solve them, and thus civilizing the individual and the society.

\section{Curricula and Social Issues}

Carried out in a purposeful, planned, systematic and programmed manner through an educational institution, instruction (generally) is realized in a purposeful manner, within a certain programme. Thus, instruction is the systematic guiding of learning (Simsek, 2011). In the design of the curriculum, in other words, in the design of the instructional guides which include which include the details regarding the application of the educational programmes in the classroom there are three approaches: Theme-based, learner-based and problem-based approaches (Demirel, 2002). Theme-based curricula focus on universal knowledge. Learner-based curricula, require students' own observations, experiences and learning efforts, that is, their effective participation. The curricula are prepared in consideration of the students' interests and needs, and individual differences. Problem-based curricula, on the other hand, involve social issues and aim to raise individuals that can solve problems for the restructuring of the society (Alici, 2012, Aykac, 2014; Sonmez, 2012). Topics are chosen from a range of topics related to social life, and students are expected to apply what they learn in life, thus adapting to the real world and its ever-changing conditions (Demirel, 2002).

Ralph Tyler argues that in order to evaluate the effect of instruction on the students, in other words, the attainments gained by the students following the instruction, it is essential to assess students' way of thinking, unconventional behavior forms, study habits, study skills, what they appreciate, and above all their social sensitivities (Stone, Madaus, Stufflebeam \& Tyler, 1990). So, curricula, which are the guides followed throughout instruction, are supposed to provide the students with new perspectives, unconventional behavioral patterns and social sensitivity. However, it is impossible to isolate the new perspectives, the new behavioral patterns and the social sensitivity, that is, the training guided through curricula, from the society, from the culture or even from the social issues in which the students live (Rubin, 1991). For example, "individuality, competition, creativity, and freedom to choose government officials" are included as goals in the curricula in the USA while "loyalty to the state" and "subordination of one's individuality to the welfare of the community" are the goals of the curricula in Russia (Ornstein, Pajak \& Ornstein, 2011, p. 13).

Since the foundation of the Turkish Republic, curricula have always been changed depending on the current needs and the prevailing ruling ideology (Demirel, 2002). Having undergone radical alterations in 1924, 1926, 1936, 1948, 1962, 1968, 1998 and 2004 (Ulutas \& Erman, 2011), the curriculum has been recently updated in 2018. The goal of the curriculum developed in 1924 was to enable the young citizens of the Turkish Republic to acquire the knowledge and learn the technology of that particular period. In this context, the curricula were based on lab works, experiments and observation (Akyuz, 2005). Curricula in 1926 were designed according to the Unification of Education Law (Law no: 430), whereby the secular education system was established. In the programmes prepared separately for boys and girls, the meaning and importance of the republic, the newly adopted regime of the country, were emphasized. In the 1926 curriculum, which was based on learning by doing method, students would receive vocational training in consideration of their interests (Orakci, Durnali \& Ozkan, 2018). In the curriculum that was put into practice in the urban primary schools in 1936, the old curriculum was updated in terms of social, natural and technological developments. During that period, when the country was under a single party rule, in order to raise citizens according to the principles of "republicanism, populism, nationalism, laicism, statism, reformism", goals that included those principles were integrated into the curriculum in accordance with the educational ideas of the single party. During that same period, the curriculum that was designed in 1930 for rural schools and was comprised mostly of agriculture and stockbreeding was implemented in the schools in the countryside (Binbasioglu, 1995, cited in Akinoglu, 2005).

The curriculum that was put into practice in 1948 was designed in keeping with the social needs of the nation, environmental conditions and demands of the century, and was the first national curriculum. However, considering the circumstances of the time, it was difficult to reach the general goals defined in the curriculum of 1948 (Ekinci, 2016; Orakci, Durnali \& Ozkan, 2018). On top of that, all the goals of the curriculum were based on cognitive ability. Before the curriculum of 1968 was put into practice, a pilot project was carried out for five years. It took into consideration the local characteristics and current conditions of the country. The curriculum of 1968 aimed at meeting the basic learning needs of the students, and it encompassed affective and kinesthetic domains, in addition to the cognitive one (Gurkan \& Gokce, 1999). In the curriculum of 1998, put into practice after the adoption of an eight-year compulsory education, natural and social studies were included in the programme along with actual life learning (Akinoglu, 2008).

The curricula introduced in 2004 are different from the previous ones. As a result of the negative results obtained from the international comparison tests (TIMSS, PISA, etc.) that were implemented in the Turkish education system during that period, radical changes were called for in the education system, just like in other countries that participated in the tests and got negative outcomes (Ozen, 2011). In the curriculum of 2004, designed with a student-centered and 
constructivist approach, the goals and attainments contain four basic components: Social, individual, historical and cultural, and economic (Koc, Isiksal \& Bulut, 2007). In this curriculum, where every student was accepted as unique, and individual differences and intelligence types were taken into consideration, it was important that students would be successful throughout their education and that they would stay physically and psychologically healthy (Bas, 2011). With the curriculum, the students were expected to have academic, vocational and personal development opportunities, grow psychologically, morally, socially and culturally, realize historical and cultural values, know their rights and responsibilities of their society, be sensitive to democratic values and human rights, socialize, engage in sports and, above all, achieve awareness regarding the issues of the society that they live in. Moreover, the curriculum also aims to pave the way for sustainable economic growth, meet the need for qualified manpower through education and encourage entrepreneurship, via curricula, in the citizens in accordance with the global developments (Orakci, Durnali \& Ozkan, 2018).

Its update completed, the new curriculum, discussed and revised in accordance with the public opinion, was introduced in 2017-2018 educational year. In the press release made by the Minister of Education, regarding the update of the program, it is emphasized that the "curriculum will serve the society, increase prosperity, create peace, and serve the needs of the society" (Hurriyet, 2017). This discourse shows that the current government specifically included elements for solving the problems of the country in the curriculum designed for compulsory education in Turkey (high schools were also included in the compulsory education in 2012). In fact, while social, individual, historical and cultural, and economic goals that were part of the 2004 curriculum are reiterated in the new curriculum, unlike the old one, a new sense of curriculum is offered that is set according to the Turkey Qualifications Framework (TQF), that mentions areas peculiar to all disciplines, and is linked to basic level skills and competences. Upon scrutiny, it is seen that the curriculum was created based on the general aims and basic principles of Turkish national education expressed in the Basic Law of National Education No. 1739, and that the aim of the curriculum is "... to raise individuals possessing knowledge, skills and behaviors integrated with our values and competences". Values that constitute the curriculum are: "Our very own legacy, refined from the national and spiritual resources of our society, from the past to the future". The competences defined in the curriculum are skills that they will need, on a national and international level, in their personal, social, academic and business life. The eight key competences in TQF are as follows: Communication in mother tongue, communication in foreign languages, mathematical competence and basic competences in science/technology, digital competence, learning how to learn, social and citizenship-related competences, taking initiatives and entrepreneurship, cultural awareness and expression (Turkey Vocational Qualifications Authority, 2015). This way, a more compact curriculum design is offered, defined with themes encompassing learning areas specific to every discipline, comprising values education, relating to the subject area of every discipline, and with attainments planned for themes for every education leyel in such a way that they are both separate and complement each other (MoNE Curriculum and Monitoring System).

Social issue is defined as "originating from the conditions of the social environment, affecting a big part of the society, conflicting with certain social values, and requiring the use of social power and instruments to fix it" (Ozankaya, 1975; Rose, 1964; Rubington \& Weinberg, 2003; Thodorson \& Thodorson, 1969, as cited in Yilmaz, Gocen \& Yardimci, 2017). In his book titled "Toplumbilim [Sociology]" (2004), Ozankaya explains the conditions that bring about the social issues as the failure of social organizations and institutions in organizing the relations among individuals, the dysfunction of social institutions, disobeying the laws, social values not being transferred from one generation to the next, and the change of expectations (cited in Solmaz, 2004). So, it should be debated whether education, which is a social service, solves social issues or it is the source of them. In this study, it is analyzed whether the social problems identified in the Turkish Republic and the possible solutions to those social issues are included in the curriculum that is currently in use at the elementary education level.

\section{Methodology}

The research is a qualitative study based on document review and the data obtained were digitized through descriptive analysis. Document review "is the analysis of the written material containing information about the events and phenomena within the scope of the research" (Yildirim \& Simsek, 2006, p. 140). Descriptive analysis, on the other hand, is an analytical approach in which "the data summarizing according to the determined themes" (Yildirim \& Simsek, 2006, pp. 227, 224) and "digitized and interpreted according to the themes set" (Dawson, 2009, p. 122) . In this context, specific goals, themes (learning areas, units) and attainments defined in the curriculum that was designed for 19 disciplines (given in the Appendix 1) and put into practice as of 2018-2019 education year at the elementary education level (primary, secondary school) make up the data source of the study. In the study, e-Delphi technique was used to determine the social issues. "In the area of expertise regarding the research topic assumed to be" (Ziglio, 1996, p. 21, cited in Somerville, 2008) "the primary source of the projected information" (McKitrick, 2007, cited in Wiebe et al., 2009), three rounds of e-Delphi panels were organized with sociologists from different Turkish universities. The reason of the selection of the teaching staff of the sociology department in the research was: One of the main fields of study of sociology is "applied sociology" and this field is concerned with using sociological problems to solve social problems (Bueno, 2017). Then, sociologists were considered the main source for the detection of Turkey's social 
problems in this research. All the research process related to listing social problems and examining the status of these problems in the curriculum is summarized in Figure 1.

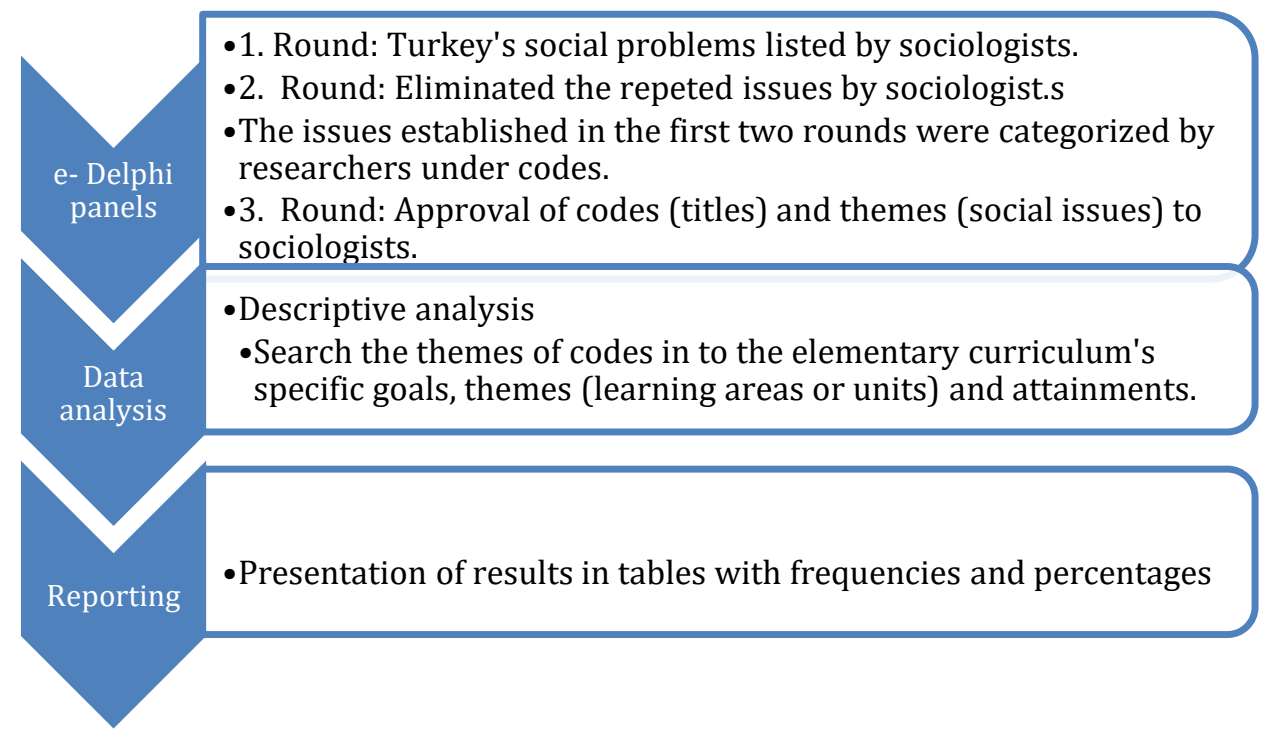

Figure 1. The process of research

In the 2017-2018 education year, there are sociology departments in 109 of the Turkish higher education institutions (Higher Education Board, 2019). In the first two rounds of the panels, participating sociologists were asked to list the social issues they identified in Turkey. To that end, 70 sociologists that work in the sociology departments or in relevant fields were sent the research questions (in the selection of sociologists to participate in the panel sociologists those who completed their doctorate in sociology, and those who shared their e-mails and resumes on the contact page of their universities were preferred.). Forty-seven sociologists provided feedback in the first round of the panel. The number of social issues reported by the sociologists in the first round corresponded to 297. In the second round, sociologists were asked to eliminate the issues they thought were repetitions, and to add the issues they forgot to mention. In the second round, 27 participating sociologists reduced the number to 110 after revising the list. And in the final round, the issues established in the first two rounds were categorized by researchers under seven codes, and the issues (themes) related to the codes were sent to the participating sociologists for approval. Four participating sociologists suggested alterations regarding the list of issues categorized under codes. Other sociologists were assumed to have approved the list codes as it is.

The social issues (110 themes) in Turkey identified and categorized under seven codes in line with the sociologists' views are as follows:

Code 1. Issues related to family: Under this title related themes are domestic violence (sexual, emotional, physical violence towards the child, the woman, the elderly), divorce, failure to instill a sense of responsibility to the young and children, the degeneration of family values, the disappearance of family culture, raising the individuals without a strong personality, failure to create a democratic structure within the family (division of labor based on gender among parents or different-sex siblings).

Code 2. Issues related to education: Under this title related themes are dropout, failure to access educational services, the education system becoming market-oriented, lack of quality in education, higher education and exams, pre-school education failing to become prevalent, education not emphasizing social values enough (limited values education).

Code 3. Issues related to socialization: Under this title related themes are social gender inequality, abuse of women, gender apartheid, honor killings, child abuse, violence in and out of school, lack of communication, corruption in moral values, failure to create social unity and solidarity, failure to unite around common values, social exclusion, lack of respect, social violence, lack of trust, lack of solidarity, failure to consider collective interests, individualism, refugees issue, violence in media and the loss of values becoming normal, cultural disintegration, cultural alienation, being unethical.

Code 4. Issues related to democratic life, democratization and government: Under this title related themes are the young serving certain interest groups with insensible political attitudes, limitation of liberties, favoritism, cultural discrimination, religious discrimination, ethnic discrimination, language discrimination, inequality, insensitivity to differences, marginalization, breaches of human rights, anomie becoming the norm, lack of freedom of press, media's lack of ethics, limitation of freedom of expression, intolerance, lack of participation, submission to a person, lack of organization, political instability, culture of bossism, lack of social, economic and cultural rights, issue of interinstitutional relations, issue of constitutional organization and the separation of powers, dependency of civil society on the political power, indifference to and mistrust in the civil society, issue of justice, lack of political representation, 
issues of parliamentary democracy, coups, interventions in the politics, lack of transparency, issue of minority rights, lack of citizenship awareness, lack of democracy awareness.

Code 5. Issues related to the environment and urbanization: Under this title related themes are traffic insecurity, rise in crime rates, lack of health services, lack of social security, terrorism, anarchism, lack of planning, food insecurity, failure to create a disabled-friendly environment, rise of crime and deviant behavior with urbanization, unplanned urbanization, migration, environmental pollution, ecological issues, hostility towards forests and nature, unpreparedness in the face of natural disasters, and practices of unearned income.

Code 6. Issues related to individual life and individualization: Under this title related themes are unconscious internet and social media use, substance abuse, smoking, drinking, addiction to television and computer, inauthenticity, issues of body perception, irresponsibility, moral collapse, lack of exercise, malnutrition, excessive fondness of self-image, issue of identity and sense of belonging, ignorance and lack of capacity in certain positions of power.

Code 7. Economic issues: Under this title related themes are child workers, lack of work safety, unregistered employment, unfair distribution of wealth, consumerism, credit in blank, unemployment, youth and graduate unemployment, lack of work ethic, rise in desire to earn fast and easy money, female unemployment, poverty, insufficient budget for education due to low and unfair distribution of wealth.

The list made with the above mentioned codes (and themes belong to these codes) were related to the specific goals, themes (learning areas or units), attainments defined in the curriculum used at the elementary education level in Turkey. Those considered to be related to identified codes, in other words, those considered to be a solution to the problems identified were counted by two examiners (one of the examiners is an expert in education programs and the other in education management) throughout the curriculum. The consistency ratio between the two examiners was assessed using Holst's Method. According to the method, the consistency ratio between the two examiners is: The ratio of the consistency number between two examiners against the sum of the number of units coded by the two examiners [Consistency Ratio = Number of Consistencies between Two Examiners / Total Number of Units Coded by Examiners A and $\left.B ; P A_{0}=2 A /\left(n_{A}+n_{B}\right)\right]$, and for reliability this number should vary between 0 and 1 (Neuendorf, 2002, p. 108). After the transaction, the consistency ratio between the two examiners is .98 for specific goals of the subjects, .99 for themes (learning areas and units), and .94 for the attainments.

\section{Findings / Results}

In line with the themes set by researchers, descriptive analysis was applied to the 19 curricula of subjects being used in 2018 (in this case, the foreign language curricula is excluded), whose specific goals were set and designed based on attainments connected with themes (learning areas or units). Within the scope of the research, a total of 111 themes (learning areas or units), 196 specific goals of subjects and 3326 attainments are defined in 19 subjects curricula (Appendix 1) that were examined (MoNE BoE Curriculum and Monitoring System). The data obtained from the descriptive analysis are presented in tables (Table 1,2,3), according to the seven codes (issues related to family, issues related to education, issues related to socialization, issues related to democratic life, democratization and government, issues related to environment and urbanization, issues related to individual life and individualization, economic issues) with sample themes, specific goals and attainments of 19 subjects.

Table 1. The inclusion of social issues in the themes (learning area or units) of elementary education curriculum

\begin{tabular}{|c|c|c|c|}
\hline Codes & $\begin{array}{c}\text { Inclusion } \\
\text { (Times) }\end{array}$ & Percentage & Sample Learning Area/Unit of 19 subjects \\
\hline Code 1 . Issues related to family & 5 & 5.20 & $\begin{array}{l}\text { ITA. A hero is born } \\
\text { HB. Life at home }\end{array}$ \\
\hline Code 2 . Issues related to education & 13 & 13.54 & $\begin{array}{l}\text { T. Virtues } \\
\text { T. Our national culture } \\
\text { T. War of Independence and Ataturk }\end{array}$ \\
\hline Code 3 . Issues related to socialization & 25 & 26.04 & $\begin{array}{l}\text { SB. Culture and inheritance } \\
\text { T. Communication } \\
\text { Y. Consensus } \\
\text { Y. Cohabitation } \\
\text { BT. Ethics and security }\end{array}$ \\
\hline $\begin{array}{l}\text { Code } 4 \text {. Issues related to democratic } \\
\text { life, democratization and government }\end{array}$ & 15 & 15.63 & $\begin{array}{l}\text { SB. Active citizenship } \\
\text { ITA. Democratization efforts } \\
\text { T. Rights and freedoms } \\
\text { T. Citizenship } \\
\text { SHA. Law and justice in our lives }\end{array}$ \\
\hline
\end{tabular}


Table 1. Continued

\begin{tabular}{|c|c|c|c|}
\hline Codes & $\begin{array}{c}\text { Inclusion } \\
\text { (Times) }\end{array}$ & Percentage & Sample Learning Area/Unit of 19 subjects \\
\hline $\begin{array}{l}\text { Code } 5 \text {. Issues related to environment } \\
\text { and urbanization }\end{array}$ & 12 & 12.5 & $\begin{array}{l}\text { F. Organisms and life } \\
\text { O. Security in traffic } \\
\text { HB. Life in nature }\end{array}$ \\
\hline $\begin{array}{l}\text { Code } 6 \text {. Issues related to individual life } \\
\text { and individualization }\end{array}$ & 25 & 26.04 & $\begin{array}{l}\text { SB. Science, technology and society } \\
\text { T. Virtues } \\
\text { T. Health and sports } \\
\text { TDB. Faith and man } \\
\text { TDB. Islam and morals } \\
\text { SHA. Law and justice } \\
\text { BE. Active and healthy life }\end{array}$ \\
\hline Code 7. Economic issues & 1 & 1.04 & SB. Production, distribution and consumption \\
\hline Total & 96 & 100 & \\
\hline
\end{tabular}

When elementary education curriculum is examined in the context of learning areas or unit titles, it is understood that, in the 19 curricula used at elementary education level in Turkey, "issues related to socialization" and "issues related to individual life and individualization" were included most, respectively, and there are too few learning areas or units that touched on "economic issues".

Table 2. Inclusion of social issues in the specific goals of elementary education curriculum

\begin{tabular}{|c|c|c|c|}
\hline Codes & $\begin{array}{c}\text { Inclusion } \\
\text { (Times) }\end{array}$ & Percentage & Sample specific goals of 19 subjects \\
\hline Code 1 . Issues related to family & 9 & 5.96 & $\begin{array}{l}\text { SB. As free individuals, students will be able to } \\
\text { become aware of their physical, emotional attributes, } \\
\text { and their interests, and abilities. } \\
\text { HB. Students will have the basic values of family and } \\
\text { society. }\end{array}$ \\
\hline $\begin{array}{l}\text { Code } 2 . \text { Issues related to } \\
\text { education }\end{array}$ & 15 & 9.93 & $\begin{array}{l}\text { TT. Students will be able to contribute to the } \\
\text { transformation of scientific knowledge and } \\
\text { technology into innovative products through creative } \\
\text { thinking systems. } \\
\text { S. Students will get to know the cultural values, } \\
\text { abstract and concrete, of their city. }\end{array}$ \\
\hline $\begin{array}{l}\text { Code } 3 . \text { Issues related to } \\
\text { socialization }\end{array}$ & 49 & 32.45 & $\begin{array}{l}\text { SB. As citizens of the Turkish Republic, students will } \\
\text { become citizens with national consciousness who } \\
\text { love their country and nation, know and wield their } \\
\text { rights, and fulfill their responsibilities. } \\
\text { T. Students will be able to realize and embrace } \\
\text { aesthetic and artistic values through works of the } \\
\text { Turkish and global culture and art. } \\
\text { F. Students will be able to realize the mutual } \\
\text { interaction between environment and society, and } \\
\text { will become aware of the sustainable growth related } \\
\text { to society, economy and natural resources. } \\
\text { M. Students will be able to value mathematics with } \\
\text { the awareness that mathematics is a common value of } \\
\text { humanity. }\end{array}$ \\
\hline
\end{tabular}


Table 2. Continued

\begin{tabular}{lr}
\hline Codes & \\
& \\
\hline Code 4. Issues & related to \\
democratic & life, \\
democratization & and \\
government &
\end{tabular}

government

Code 5. Issues related to environment and urbanization

Code 6. Issues related to individual life and individualization

\section{(Times)} 16.56

16.56

\section{Sample specific goals of 19 subjects}

Percentage

\section{SB.} issues

Y. Students will be able to grasp the meaning and importance of the concepts like human rights, national sovereignty, total independence, nationalism, democracy, modernity, secularism and republic.

SHA. Students will be able to become literate in law, with a high level of consciousness for law and justice.

Y. Students will be able to appreciate justice and equality to improve human rights and democratic culture.

Y. Students will be able to take responsibility to improve the conditions for cohabitation.

BE. Students will be able to develop communication skills, collaboration, fair play, social responsibility, leadership, sensitivity to nature and respect for differences through physical education and sports.

SB. Students will be able to get to know their surroundings and the general geographical features of the world, grasping the interaction between man and environment, improving their space perception skills.

HB. Students will become sensitive to the nature and environment.

TG. Students will be able to offer new suggestions to prevent and solve traffic problems.

TT. Students will acquire free, authentic and innovative thinking skills.

O. Students will be able to improve skills such as selfknowledge, individual responsibility, self-confidence and time management through games and physical activities.

0 . Students will be able to improve skills such as selfknowledge, individual responsibility, self-confidence and time management through games and physical activities.

Y. Students will assume responsibility to wield rights and freedoms.

SB. Students will be able to grasp the development process of science and technology and their effects on the social life, using information and communication technologies consciously.

SB. Students will be able to understand the basic concepts of economics, appreciating the importance of national economy in development and international economic relations.

SB. Students will believe in the importance of working in social life and that every occupation is necessary and should be respected.

\begin{tabular}{lll}
\hline Total & 151 & 100 \\
\hline
\end{tabular}

When you examine the specific goals of the curriculum for 19 subjects used in elementary education, together with the list of social issues compiled, it is seen that the curriculum used at the elementary education level includes, the "issues 
related to socialization" and "issues related to individual life and individualization" with frequency in its special goals. In special goals "issues related to democratic life, democratization and government" are defined as well. The least frequently encountered social issue in the curriculum was found to be "economic issues".

Table 3. Inclusion of social issues in the attainments of elementary education curriculum

\begin{tabular}{|c|c|c|c|}
\hline Codes & $\begin{array}{c}\text { Inclusion } \\
\text { (Times) }\end{array}$ & Percentage & Sample attainments of 19 subjects \\
\hline Code 1 . Issues related to family & 24 & 2.62 & $\begin{array}{l}\text { SB. Students will be able to research elements } \\
\text { that reflect the national culture in their families } \\
\text { and surroundings, providing examples. } \\
\text { SB. Students will take responsibility for their } \\
\text { actions in family and school life. } \\
\text { SB. As individuals aware of their rights, students } \\
\text { will act in line with their duties and } \\
\text { responsibilities that their roles require in the } \\
\text { groups they join. }\end{array}$ \\
\hline
\end{tabular}

Code 2. Issues related to education

Code 3. Issues related to socialization

Code 4. Issues related to democratic life, democratization and government
ITA. Students will grasp the importance Ataturk, having held an education congress, attaches to national and modern education during a tough time in the independence war.

SB. Students will be able to research elements that reflect the national culture in their families and surroundings, providing examples.

** Students will appreciate the importance and necessity of love and respect for the improvement of human relations.

**Students will realize the role religion plays in the individual's good morals.

** Students will take special care to mind their manners in social life.

** Students will appreciate the contribution of religious festivals and important days to the social integration.

$\mathrm{Mu}$. Students will listen to the national anthem with respect.

Y. Students will appreciate the effect of rights and freedoms on the cohabitation culture.

O. Students will be able to perform cultural folk dances with simple rhythms.

ITA. Students will be able to analyze practices followed in line with the National Tax Orders as an example of national unity and solidarity of the Turkish nation.

ITA. Students will be able to analyze the developments that accelerated the transition to multi-party system in Turkey in terms of democratic exigencies.

SB. Students will put themselves in other individuals' shoes with different characteristics. SB. Students, as children, will be able to defend their rights and provide examples of breach of these rights.

SB. Students will question stereotypes of various cultures.

BE. Students will be sensitive to individual differences in games and activities. 
Table 3. Continued

\begin{tabular}{|c|c|c|c|}
\hline Codes & $\begin{array}{l}\text { Inclusion } \\
\text { (Times) }\end{array}$ & Percentage & Sample attainments of 19 subjects \\
\hline $\begin{array}{l}\text { Code } 5 . \text { Issues related to } \\
\text { environment and urbanization }\end{array}$ & 99 & 10.82 & $\begin{array}{l}\text { TT. Students will be able to explain technologies } \\
\text { for obtaining clean and sustainable energy by } \\
\text { using natural resources such as water, wind and } \\
\text { sun. } \\
\text { TT. Students will design a product that will } \\
\text { facilitate life for individuals with special needs. } \\
\text { HB. Students will obey traffic rules when } \\
\text { commuting to school. } \\
\text { HB. Students will provide examples for natural } \\
\text { disasters. }\end{array}$ \\
\hline
\end{tabular}

Code 6. Issues related to individual life and individualization
293
Code 7. Economic issues
42
4.59
0. Students will be able to perform translatory motions with increasing agility.

0. Students will join games and physical activities regularly.

O. Students will notice their personal and general space.

Y. Students will explain the responsibilities of being a citizen.

$\mathrm{Mu}$. Students will perform their own songs.

BT. Students will appreciate the effect of digital sharings on themselves and on others.

BT. Students will be able to explain methods of information protection.

HB. Students will be able to offer original suggestions for the effective and efficient use of school resources.

BT. Students will research the meaning and importance of copyright.

HB. Students will be able to offer original suggestions for the effective and efficient use of school resources.

HB. Students will research the effects of economical use of home resources on the household budget.

When you examine the attainments defined for every subject in the curriculum being used at the elementary education level in line with the codes of social issues identified by researchers, the most frequent social issues encountered in the attainments are "issues related to individual life and individualization" and "issues related to socialization" respectively. On the other hand, the least frequent social issue seems to be "issues related to family".

Table 4. The order of inclusion of social issues in the elementary education curriculum

\begin{tabular}{lccc}
\hline Social Issues (Codes) & $\begin{array}{c}\text { Order of inclusion } \\
\text { in the learning } \\
\text { area or unit }\end{array}$ & $\begin{array}{c}\text { Order of } \\
\text { inclusion in the } \\
\text { specific goals }\end{array}$ & $\begin{array}{c}\text { Order of } \\
\text { inclusion in the } \\
\text { attainments }\end{array}$ \\
\hline Code 1. Issues related to family & 5 & 6 & 7 \\
$\begin{array}{l}\text { Code 2. Issues related to education } \\
\text { Code 3. Issues related to socialization }\end{array}$ & 3 & 4 & 5 \\
$\begin{array}{l}\text { Code 4. Issues related to democratic life, } \\
\text { democratization and government }\end{array}$ & 1 & 1 & 3 \\
$\begin{array}{l}\text { Code 5. Issues related to environment and } \\
\text { urbanization }\end{array}$ & 2 & 3 & 4 \\
$\begin{array}{l}\text { Code 6. Issues related to individual life and } \\
\text { individualization }\end{array}$ & 4 & 5 & 1 \\
Code 7. Economic issues & 1 & 2 & 6 \\
\hline
\end{tabular}


In the curriculum used in elementary education level that was examined within the scope of this study, the most frequent codes encountered were "issues related to individual life and individualization", "issues related to socialization" and "issues related to democratic life, democratization and government" respectively. It was found that instances that included issues related to "family" and "economy" were relatively less frequent. However, it is understood that the curriculum used at elementary education level (more or less) encompasses the issues identified by the sociologists.

\section{Discussion and Conclusion}

Basaran (1982) describes elementary education as "a learning and teaching phase that provides basic qualifications for being productive, applying society's rules, obeying society's values and norms, and solving individual and social issues every citizen will encounter in their lives" (p. 182). Elementary education is a learning level at which students learn the rules of the society, realize its values and become aware of its issues. Then the curriculum employed at this education level should provide the students with all these attainments. In this study, elements (themes identified for the subjects, specific goals of the subject, and attainments of the subject) thought to have the potential to offer solutions to social issues identified by Turkish sociologists were reviewed in the curricula designed for elementary education level, and examined to see if they are included in the curricula. All the social issues (in this study coded as: Issues related to family, issues related to education, issues related to socialization, issues related to democratic life, democratization and government, issues related to environment and urbanization, issues related to individual life and individualization, economic issues) that were identified by Turkish sociologists are included in the elementary education curriculum currently being used in Turkey.

Out of the social issues categorized by the researchers, the one that is most frequently encountered in the curricula designed for 19 subjects being used at elementary education level is "issues related to individual life and individualization". Cezayirli (2004) stresses that individual development and individualization are a prerequisite for socialization and globalization. Individual life and individualization, which involve individual's instances related to physical, cognitive and psychological development, produce solutions to the issues the individual faces in their social life, that is, in socializing and becoming a global citizen. Obviously, socialization issues, including social gender inequality, abuse, violence, lack of communication, corruption in moral values, failure to create social unity and solidarity, failure to unite around common values, and alienation will be solved only if the issues related to individual life and individualism are solved. Curricula designed for elementary education in Turkey contain elements that could provide solutions to issues related to both individual life and individualism, and social life.

One other thing that is encountered frequently in elementary education curricula is the instances that could provide solutions to issues related to democratic life, democratization and government. It is seen that elementary education curricula being used in Turkey include instances that could provide solutions to issues related to discrimination, inequality, breach of human rights and political system. For the teachers, who are the practitioners of the curricula, to make students adopt democracy as a life style, they should value students' ideas in the classroom, engage them in the activities, and set an example for them with their own attitudes and behaviors (Topal, 2007). Almogbel (2015) has examined the Saudi Arabian curricula in the context of international education issues, and carried out a research in which he compared the curricula in use with the curricula in practice in the USA and the UK. According to the findings of the research, unlike the curricula of the countries with which they were compared, curricula being used in Saudi Arabia do not include universal values such as peace, human rights and multi-culturalism. Sen (2018), in his research, points out to an important phenomena regarding the citizenship education curriculum in which democratic life practices are taught most extensively. In his research, he examined changes and the role of international organizations in these changes after 1995 in citizenship education. He states that the reform in citizenship education curriculum in Turkey started with Turkey signing the United Nations Human Rights Declaration, but that this reform is being tried to be implemented without sufficient analysis, without realizing Turkey's human rights and democracy problems.

Skills and attainments obtained through education and learning not only pave the way for the individual's future learnings but also facilitate the problem solving processes (Yayci, Ilhan \& Sarikaya, 2018). According to Simsek (2011), "primary benefit of designing the content in such a way as to go from problems to solutions is that students are encouraged to put in an effort to find solutions to problems" (p. 157). In fact, one of the issues identified by sociologists in Turkey is the issues related to environment and urbanization. The research results of Sogancilar and Uzoglu (2018) show that students have the necessary knowledge about recycling and that they also want to participate in recycling related endeavors voluntarily.

In this research, one other issue identified by the sociologists is economic issues. Results of the research, in which Amagir, Groot, Maassen van den Brink and Wilshut (2018) researched the effect of financial literacy education on children and adults, show that financial literacy education had a positive impact on both adults' and children's knowledge and attitudes in financial matters. However, researchers emphasize that since the results they obtained are based on self-reports of the participants, they may not reflect the real spending and consuming behaviors. Therefore, the inclusion of economic issues in the curriculum does not necessarily mean that students can cope with those issues, and become good producers and consumers. Aquah (2014) argues that the curricula designed for national economic 
development and sustainable employment should take into account the needs of the global workforce market as well as the needs of the country it is designed in. What is done for the sake of economic development can be the cause of other social issues as well. For instance, Parker's (2016) research results for the new curriculum regarding Indonesia's environmental education show that the programme included economic development, but neglected the relation between development and environment. This result indicates that the issues included in the curricula need to be linked together. As the matter of fact, Michie (2017) points out the importance of being an "integrative" rather than "integrated". Integrated is generally used to imply that the content of the course (subject) comes from across the disciplines. Integrative has been used elsewhere to imply inclusion of social and cultural (including cross-cultural) aspects. Merton (1934) argues that all human behaviors (including the behaviors creating social issues) are interrelated. Thus, social issues are interrelated. Moreover, a solution to a social issue may end up being the root cause of another issue (cited in Fine, 2006). In this regard, it is likely that the curricula expected to provide solutions to Turkey's social issues might bring about other social issues, as well as offering solutions to social issues in the future. Moreover, there are some research results showing that there is a difference between the intended, perceived and implemented curriculum (for example: Levitt, 2001; Smith \& Southerland, 2007).

Another thing about curricula is the materials used in the classroom throughout the educational period, which are the concrete reflections of the curriculum. Since books are the most frequently used materials, they should reflect the curricula. Ipek (2011) did a research to see whether social studies and citizenship books are compatible with the curricula. Although "raising active citizens" is a goal of social studies curriculum, results show that the examples used in the course books are contradictory. Alaca's (2017) research results indicate that the content of social studies books designed after 1985 was influenced by the political developments of that period, and the texts in the books, the books and even the publishing houses of the books reflected the dominant ideology of that particular period. Dobrocká and Szórádová's (2017) qualitative research results, in which they examined the music curriculum used during the war between Czechoslovakia and Slovakia (1918-1939), aiming at shaping the national identity, show that the programme laid the foundation for implicit social ideas and ideological actions, reflecting the ideologies, opinions and values of the actors of education of that period. Gress and Shin (2016) established that, although green energy is included in the Korean primary curriculum, the number of texts containing green energy is limited in the geography books designed in line with this curriculum. According to the researchers, this poses a challenge in informing the civil society about green energy for sustainable growth and in transforming that information into action. In light of these results, it is understood that even if the curricula are designed perfectly, special care should be taken preparing the teaching materials, through which the curriculum content is presented.

Realizing the objectives and achieving the goals of the curricula used at elementary education level depend, in a way, on the ability of the teachers, practitioners of the programme, and the school administration to manage and apply the programme. For instance, in the Philippines, where compulsory education was increased to 12 years from ten, the Philippine teachers regard themselves proficient regarding the execution of the newly designed curricula. In fact, teacher training centers in the country are ready to train teachers that can successfully execute the curriculum, thus realizing the great educational reform (Acosta \& Acosta, 2017). According to the results of the research carried out by Sarigoz and Bolat (2018) with teacher candidates, although teacher candidates feel confident about curriculum literacy, understanding, interpreting and assessing the curriculum, they feel inadequate regarding curriculum goals. This result suggests that teachers' qualifications also need to be improved, who are the practitioners of the new curricula expected to offer solutions to the social issues.

\section{References}

Acosta, I. C. \& Acosta, A. S. (2017). A mixed methods study on teachers' perceptions of readiness of higher education institutions to the implementation of the k-12 curriculum. Universal Journal of Educational Research, 5(7), 12151232. doi: 10.13189/ujer.2017.050714.

Akinoglu, O. (2005). Turkiye'de uygulanan ve degisen egitim programlarinin psikolojik temelleri [Changing psychological foundations of education programs implemented in Turkey]. M. U. Ataturk Egitim Fakultesi Egitim Bilimleri Dergisi, 22, 31-46. Retrieved from http://dergipark.gov.tr/download/article-file/1743

Akinoglu, O. (2008). Primary education curriculum reforms in Turkey. World Applied Sciences Journal, 3(2), $195-199$. Retrieved from https://files.eric.ed.gov/fulltext/ED503451.pdf

Akyuz, Y. (2005). Turk egitim tarihi [History of Turkish education]. Ankara: PegemAkademi.

Akyuz, Y. (2012). Turkiye'de ogretmelerin toplumsal degismedeki etkileri (1839-1950) [Impact of teachers' on social change in Turkey (1839-1950)]. Ankara: PegemAkademi.

Alaca, E. (2017). An evaluations of social studies coursebook. Education and Society in 21st Century, 6(18), $759-785$. Retrieved from http://dergipark.gov.tr/download/article-file/444194

Alici, B. (2012). Egitim programi tasarimi ve modeller [Training program design and models]. H. Seker (Ed.), In Egitimde program gelistirme [Curriculum development in education] (pp. 71-88). Ankara: Ani. 
Almogbel, A. N. (2015). International education issues in Saudi Arabia's public education curricula: An analytical study. Journal of International Education and Leadership, 5(1), 1-24. Retrieved from https://files.eric.ed.gov/fulltext/EJ1135344.pdf

Amagir, A., Groot, W., Maassen van den Brink, H., \& Wilschut, A. (2018). A review of financial literacy education programs for children and adolescents. Citizenship, Social and Economics Education, 17(1), 56-80. doi: $10.1177 / 2047173417719555$

Aquah, P. A. (2014). Enriching the business education curriculum for relevance in the global workforce. Global Journal of Human-Social Science: G Linguistics \& Education, 14(7), 30-35. Retrieved from https://globaljournals.org/journals/human-social-science-journal

Aykac, N. (2014). Ogretim ilke ve yontemleri [Teaching principles and methods]. Ankara: PegemAkademi.

Bas, G. (2011). Turkiye'de egitim programlarinda yapilandirmacilik: Dun, bugun, yarin [Constructivism in curriculum in Turkey: Yesterday, today, tomorrow]. Egitisim Dergisi, 32 . Retrieved from http://www.egitisim.gen.tr/tr/index.php/arsiv/sayi-31-40/sayi-32-ekim-2011/739-turkiye-de-egitimprogramlarinda-yapilandirmacilik-dun-bugun-yarin

Basaran, I. E. (1982). Temel egitim ve yonetim [Basic education and management]. Ankara: Ankara University.

Bueno, C. F. (2017). Areas of sociology. Retrieved from https://owlcation.com/social-sciences/Areas-of-Sociology

Cezayirli, G. (2004). Kuresellesme, bireysellesme ve toplumsallasma [Globalization, individualization and socialization]. Erdem [Virtue], 14(41), Retrieved from http://dergipark.gov.tr/erdem/issue/5927/78381

Dawson, C. (2009). Introduction to research methods: A practical guide for anyone undertaking a research project. Oxford: How to Books.

Demirel, 0. (2002). Kuramdan uygulamaya egitimde program gelistirme [Curriculum development from theory to practice]. Ankara: PegemA.

Dobrocká, S., \& Szórádová, E. (2017). School curriculum as a means of shaping national identity: Music education in the Slovak region of Czechoslovakia in the interwar period (1918-1939). Pedagogy, Culture \& Society, 26(2), 165-179. doi: 10.1080/14681366.2017.1365751

Ekinci, N. (2016). Turkiye'de cok partili duzene geciste dis etkenler [External factors in the transition to multi-party system in Turkey]. Ankara: Gece.

Fine, G. A. (2006). The chaining of social problems: Solutions and unintended consequences in the age of betrayal. Social Problems, 53(1), 3-17. doi: 10.1525/sp.2006.53.1.3

Gurkan, T \& Gokce, E. (1999). Turkiye'de ve cesitli ulkelerde ilkogretim [Elementary education in Turkey and various countries]. Ankara: Siyasal.

Gress, D. R., \& Shin, J. (2016). Potential for knowledge in action? An analysis of Korean green energy related K3-12 curriculum and texts. Environmental Education Research, 23(6), 874-885. doi: 10.1080/13504622.2016.1204987

Hidmi, N. S. (2017/2018). Imposing the Israel curriculum on Palestinian Jeruselam schools: The Shovel destroying our national identity. Palestina-Israel Jounal of Politics, Economics and Culture, 22/23(4/1), 44-48.

Higher Education Board (2019). All universities with sociology program. Retrieved from https://yokatlas.yok.gov.tr/lisans-bolum.php?b=10195

Hurriyet. (2017, 17 July). Turkish education ministry reveals new curriculum: Evolution out, 'jihad' in. Retrieved November 20, 2018 from http://www.hurriyetdailynews.com/turkish-education-ministry-reveals-newcurriculum-evolution-out-jihad-in-115673

Ipek, I. (2011). Assessment of citizen education primary 6th and 7th grade social studies course book and objectives of social studies teaching's curriculum in terms of appropriateness. (Master thesis). Retrieved from file:///C:/Users/DELL/Downloads/279381.pdf

Koc, Y., Isiksal, M. \& Bulut, S. (2007). Elementary school curriculum reform in Turkey. International Education Journal, 8(1), 30-39. Retrieved from https://files.eric.ed.gov/fulltext/EJ841629.pdf

Law No: 430. Tevhid-i Tedrisat Yasasi [Unification of Education Law] (1924, 03 March). Official Newspaper (No: 63). Retrieved from: http://www.mevzuat.gov.tr/MevzuatMetin/1.3.430.pdf

Levitt, K. E. (2001). An analysis of elementary teachers' beliefs regarding the teaching and learning of science. Science Education, 86(1), 1-22. doi: 10.1002/sce.1042 
Michie, M. (2017). Comparing the Indonesian kuriculum 2013 with the Australian curriculum: Focusing on science for junior secondary schools. The International Education Journal: Comperative Perspectives, 16(2), 83-96. Retrieved from https://openjournals.library.sydney.edu.au/index.php/IEJ/article/view/11031

Ministry of National Education (MoNE). Board of Education (BoE). Curriculum Monitoring and Evaluation System. Retrieved November 03, 2018 from http://mufredat.meb.gov.tr/Veliler.aspx; http://mufredat.meb.gov.tr/ProgramDetay.aspx?PID=326; http://mufredat.meb.gov.tr/Programlar.aspx

Neuendorf, K. A. (2002). The content analysis guidebook. Thousand Oaks, CA: Sage.

Orakci, S., Durnali, M. \& Ozkan, O. (2018). Curriculum reforms in Turkey. O. Karnauhkova \& B. Christiansen (Editors). In Economic and Geopolitical Perspectives of the commonwealth of independent states and Eurasia (pp. 225-251). Hershey, PA: IGI Global.

Ornstein, A. C., Pajak, E. F. \& Ornstein, S. B. (2011). Contemporary issues in curriculum. Boston: Pearson.

Orogue, S.A. (1998). Enriching the tertiary curriculum for relevance and functionality. WCC Religion Forum Vol. 2.

Ozen, F. (2011). According to elementary schools principals' and teachers' opinions accountability as a tool for school development in education (Doctorate Thesis). Retrieved from file://C:/Users/DELL/Downloads/302871.pdf

Parker, L. (2016). Religious environmental education? The new school curriculum in Indonesia. Environmental Education Research, 23(9), 1249-1272. doi: 10.1080/13504622.2016.1150425

Rubin, L. (1991). Educational Evaluation: Classic Works of Ralph W. Tyler. Journal of Curriculum Studies, 23(2), 193197. doi: $10.1080 / 0022027910230210$

Sanal, M. (2016). Egitimin tarihi temelleri [Historical foundations of education] . M. Onur \& M. Sanal (Editors). In Egitim bilimine giris [Introduction to education science]. Ankara: PegemAkademi.

Sarigoz, O. \& Bolat, Y. (2018). Examination of the competencies of the pre-service teachers studying at the education faculties about the educational program literacy. International Journal of Educational Administration and Policy Studies, 10(9), 103-110. doi: 10.5897/IJEAPS2018.0566

Sen, A. (2018). Militarisation of citizenship education curriculum in Turkey. Journal of Peace Education, 1-26. doi: 10.1080/17400201.2018.1481019

Simsek, A. (2011). Ogretim tasarimi [Instructional design]. Ankara: Nobel.

Smith, K. L. \& Southerland, S. A. (2007). Reforming practice or modifying reforms? Elementary teachers' response to the tools of reform. Journal of Research in Science Teaching, 44(3), 396-423. doi: 10.1002/tea.20165

Sogancilar, M. E. \& Uzoglu, M. (2018). Determination of information levels and views on the recycling of secondary school students. The Journal of Social Science, 5(29), 91-108. doi: 10.16990/SOBIDER.4536

Solmaz, Y. (2004). A model for solving the problems of the urban, as the urban enstitute (Master thesis). Istanbul, Turkey: Yildiz Technical University / Institude of Science.

Sonmez, V. (2012). Program gelistirmede ogretmen elkitabi [Teacher manual for curriculum development]. Ankara: Ani.

Stone, J. C., Madaus, G. F., Stufflebeam, D., \& Tyler, R. W. (1990). Educational evaluation: Classic works of Ralph W. Tyler. Educational Evaluation and Policy Analysis, 12(1), 102-106. doi: 10.2307/1163590

Summerville, J. A. (2008). Critical factors affecting the meaningful assessment of student learning outcomes: A Delphi study of the opinions of community college personnel. Journal of Applied Research in the Community College, 15(2), 109-119. Retrieved from https://eric.ed.gov/?id=EJ897797

Topal, T. (2007). The comparison of the primary school teachers' classroom management behaviours and the relation of students' success (Doctorate Thesis). Ankara, Turkey: Ankara University Institute of Educational Sciences.

Turkey Vocational Qualifications Authority. Turkey Qualifications Framework. Retrieved November 22, 2018 from https://myk.gov.tr/index.php/tuerkiye-yeterlilikler-cercevesi

Ulutas, S. \& Erman, M. (2011). Cumhuriyetin kurulusundan gunumuze Turkiye'de uygulanmis olan ilkokul, ortaokul ve ilkogretim okullari ogretim programlarinda olcme ve degerlendirme [From founding of the Republic of Turkey to today measurement and evaluation in primary, elementary and middle school curriculums]. Journal of Measurement and Evaluation in Education and Psychology, 2(1), 148-154. Retrieved from http://www.epodonline.org/sayilar/sayi3/makale5-.pdf

Varis, F. (1998). Egitim bilimine giris [Introduction to education science]. Ankara: Alkim. 
Wiebe, E., Ho, C., Raubenheimer, D., Bullard, L., Joines,J., Miller, C. \& Rouskas, G. (2009). AC2009-676 Computing across curricula: The view of industry leaders. Retrieved http://rouskas.csc.ncsu.edu/Publications/Conferences/ASEE-CPATH-2009.pdf

Yayci, L., Ilhan, T. \& Sarikaya, Y. (2018). Mediation role of problem solving skills on the relationship between learned resourcefulness and loneliness. European Journal of Education Studies, 5(6), 1-14. doi: 10.5281/zenodo.1482924

Yildirim, A. \& Simsek, H. (2006). Sosyal bilimlerde nitel arastirma yontemleri [Qualitative research methods in the social sciences]. Ankara: Seckin.

Yilmaz, F., Gocen, S. \& Yardimci, R. (2017). The role of universities in the solution of social problems. Electronic Journal of Education Sciences, 6(12), 138-149. Retrived from http://dergipark.gov.tr/download/article-file/366329 


\section{Appendix}

Appendix 1. Abbreviations in the curricula of the subject

\begin{tabular}{lll}
\hline $\mathbf{N}$ & Subject & Abbreviation \\
\hline 1. & Social Studies & $\mathrm{SB}$ \\
2. & History of Turkish Revolution and Principles of Ataturk & $\mathrm{ITA}$ \\
3. & Turkish & $\mathrm{T}$ \\
4. & Science & $\mathrm{F}$ \\
5. & Maths & $\mathrm{M}$ \\
6. & Basic Religious Knowledge & $\mathrm{TDB}$ \\
7. & Justice and Law (Elective) & $\mathrm{SHA}$ \\
8. & The Life of our Prophet & $*$ \\
9. & Physical Education and Sports & $\mathrm{BE}$ \\
10. & Human Rights, Citizenship and Democracy & $\mathrm{Y}$ \\
11. & Games and Physical Activities & $\mathrm{O}$ \\
12. & Traffic Security & $\mathrm{TG}$ \\
13. & Art & $\mathrm{G}$ \\
14. & Life Science & $\mathrm{HB}$ \\
15. & Information Technologies & $\mathrm{BT}$ \\
16. & Technology and Design & $\mathrm{TT}$ \\
17. & Music & $\mathrm{Mu}$ \\
18. & Religious Education and Morals & $* *$ \\
19. & Our City & $\mathrm{S}$ \\
\hline
\end{tabular}

*,** There is no abbreviation for these disciplines in the curriculum. 